\title{
People Who Will Leave Their Mark on the 21st century
}

\section{Welcome by the Editor-in-Chief}

\author{
as 19 \\ Journal of Economic Literature (JEL) codes: B20, N01 \\ Keywords: economic policy, social policy, J. M. Keynes, COVID-19, Hungary
}

In the mid-1990s, following the collapse of socialism and the accompanying socialist planned economy system, a publication entitled "People Who Have Left Their Mark on the 20th Century. Lectures on the History of Ideas" was published with the participation of the then Hungarian intellectual elite (Andor et al., 1996). Nearly a quarter of a century after the book's publication, with some "intellectual import", and by correcting the title, this welcome by the editor-in-chief undertakes to provide a brief awareness-raising outreach to what is happening, but especially to the challenges ahead.

From Tibor Erdós to György Matolcsy, prominent economists discussed the fact that the Great World Economic Crisis, which "launched" the economy of the twentieth century, John M. Keynes' response to the crisis and Keynes's own theoretical work, were utterly decisive and have left their mark on the events of the century behind us. As Tibor Erdôs writes, the great depression provided far too many evidences against the idea of a self-regulating economy, and this inspired Keynes to bring about a macro-economic mind-set for radical change. Keynes's final conclusion was that if prudently used, fiscal policy (and, to a lesser extent, monetary policy) may change the aggregate demand from households, businesses and the governments as against goods and services, and thus full employment can be achieved. In other words, Keynes attributed a key role to state interventions and based on his principles the economy was successfully stabilised before and after World War II (for more details, see Keynes, 1936). W.J. Baumol rightly considered Keynes' masterpiece as the ("probably") most significant book in the twentieth century, and P.A. Samuelson described it as the "performance of an intellectual giant," and these two opinions are the cornerstones of this editorial (Samuelson, 1946, p. 190).

Yes, Keynes broke taboos, as contrary to the views of classics and monetarists, he showed in theory, and practice proved that a mode of capitalism without state inter- 
vention would be a self-regulatory system that provides full (or in today's terminology, optimum) employment. In the economic policy predominated by his ideas, the acceleration of inflation from the second half of the 1960's, then the oil crisis, and most importantly the weakening of the Bretton Woods monetary system, rapid deterioration in the constant value of the US dollar and in its capability to hold its value, which brought an end to the conversion of the U.S. currency into gold, resulted in a decline in the influence of the Keynesian teachings. However, it was a mistake to banish Keynes' thoughts, and to curb the role of his propositions in shaping the prevailing processes. The rise of monetarists in the 1970's, or in the words of Alan Greenspan, the emergence of a world without "shackles and checks," that is, a significant curtailment of the state's regulatory and supervisory role - especially in the financial sector inevitably led to a crisis. By 2007, instead of an overproduction crisis, an over-lending crisis evolved, and that, and along with the subsequent ten-year consolidation period, it showed that the active regulatory and supervisory role of the state was vital.

We Hungarians, here in the middle of Central Europe, as part of the former socialist planned economy system, and for a long time in its base dependence, have run a slightly "different trajectory" than the developed capitalist countries. Following the collapse of the cohesive socialist system, we fell victim to a fast, monetarist market economy transformation without any transitional period. Planned economy was irremediable, but the market economy transformation that took place in a short time claimed more victims than it made beneficiaries. György Matolcsy rightly "raised his voice" already in 1996: "Let's read and not bury John Maynard Keynes" (Andor et al., 1996; Matolcsy, 1999, p. 178). Yes, more Keynes, more prudent and proportionate state influence would have been needed...

The ideas of our contemporary economist László Bogár (former State Secretary in the government led by the Hungarian Democratic Forum and then in the Fidesz-led government), which may also be considered as a diagnostic report of Hungary and an action plan for the future, should be added in this context: "With the collapse of the bloc ruled by the soviet globalisation power, during the past decade Hungary set out on the road of integration into the globalisation space predominated by the American world power. This adaptation came at a huge sacrifice. All over the 20th century, only the two World Wars caused similarly enormous losses in income and wealth to Hungary as suffered during the past decade [...] Consequently, 60-70 per cent of the Hungarian population has actually come out as losers of the transformation process following the change of regime change, and about 10-15 per cent is literally "out of history" and does not stand a chance to rise. All this poses stupendous social, economic, political and cultural challenges" (Matolcsy, 1999; the quoted sentence is found on pp. 7-8). According to the vision of the future by György Matolcsy, the volume editor who embraced Bogár's thoughts, "ours is the 21st century". His focus is as follows: "Economic growth is thus the key to the Hungarian part of the global game in the 21st century: we can win the game if we follow the rules of the global space but avoid the traps that almost automatically close if the rules are followed" (Matolcsy, 1999, pp. 68-69). 
And we followed the rules. After 2010, the budget was stabilised, and the operating mechanisms applied by the National Bank of Hungary moderated inflation, while at the same time moved the economy towards growth and financial stability. Monetary policy set multiple objectives, is implemented in a macro-economic and social context, and in this modern age, a hundred years after Keynes, its role has appreciated significantly. The state's active economy organisation policy, stronger regulation and control of the markets have resulted in an impressive decade of economic development in Hungary, implemented in accordance with the principles of the Keynesian economic philosophy. It can be admitted that even in an advanced political and cultural reading, the stabilising role of the state is not a kind of a desirable and soughtafter function, or a sort of salvation, but a corporate duty to citizens who vote for or against any government. Employment increased, and together with the Visegrád group of countries (V-4), Hungary became the engine of growth in the European Union, while maintaining the budget and foreign economic balance. These events have nearly reached the period of rapid growth seen during the Austro-Hungarian Monarchy (1867-1914), described by successes.

However, the COVID-19 pandemic crisis gave a slight "shake" to the country. The way the central bank and the government are dealing with the inevitable economic downturn calls for the recovery to take place as soon as possible. We also have good reasons to focus on this topic in the English-language special issue of the 16th volume of this journal. We wish to describe the effects of the crisis on the country and to present the methodology of Hungarian crisis management. We point out that this crisis has reached us in a "stuffed" and stable condition, and it was caused by external factors, unlike the previous crises. It is in our interests to move towards a more advanced system after the pandemic, and to implement economic policy measures that will bring sustainable economy and the society closer in view.

It can be argued that the government will only be able to manage the crisis by the application of focused and effective state aid rather than intervention (remember Keynes' teachings), and with full "commitment" to the stabilising function of the state. One of the most difficult tasks, but perhaps the most honourable charge, in this crisis management is the efficient implementation and communication of consultation and feedback to both the governing and structured strata of society. Maintaining trust and preserving credibility. This may also apply to other countries, regardless of political system and historical peculiarities. This is another message of the current issue of our journal to governments and central banks dealing with the crisis all over the world.

And what about the 21st century? Obviously, everyone wants to survive this crisis, and any further crises. Both citizens and companies want to survive and remain standing. However, in a hundred years, life will span a thousand years. Processes and lifestyles are accelerating, and the economy needs to remain stable and well-managed in order to survive without wars, social unrest, and ethnic conflicts.

And who will leave their mark on the 21st century? This topic has already been raised in a previous editorial (Lentner, 2018). "A multitude of leaders and intellec- 
tuals go - overtly or covertly - after their dreams to become part of history. Among them, the well-intentioned obviously hope that the goods, systems, creations, scientific results created by them or under their control will rise to a scale that people will remember and enjoy their beneficial effects even years, decades, and centuries later. Their greatness will be included in the books, which posterity will be happy to turn to, and they will be the starting points for moving forward, becoming a point of reference."

However, no less important is the work done by people who put their hand to a plough or stand beside a turning-lathe or work three shifts day by day focusing their efforts on providing for their families and raising their children. True, we love spectacular things. Perhaps everyone loves them. But it is the daily struggle that organizes millions of families into a society and ensures sustainability. Values, traditions, love and the mother tongue can only be handed down, maintained and carried on if the smallest unit of society, the family exists. And those scientists and statesmen who promote this, and put the improvement of the lives of societies at the heart of their work, will rightly arouse appreciation from the current and future generations.

Consequently, patterns and acceptable theories will be created by thinkers who no longer want to return to the pre-crisis conditions. Because more will be in demand. The 21st century will be a period of regionalisation, digitisation, a revolution in the monetary system and taxation, and the period of green economy. Consumption habits, the social division of labour and work flows are being transformed, changes are coming, and the challenge of aging societies must be tackled. The theoreticians who will be able to create lasting things and ideas that serve the benefit of humanity will leave a mark on our lives; they will be the geniuses of the 21 st century.

It is worth reading Polgári Szemle and about Hungary.

Budapest, Advent of 2020

Dr Csaba Lentner, university professor

Editor-in-chief of Polgári Szemle

\section{REFERENCES}

Andor, L.; Berend T. I.; Erdôs, T.; Erényi, T.; Földes, Gy.; Havas, P.; Matolcsy, Gy.; Surányi, Gy. and Szigeti, P. (1996): Akik nyomot hagytak a XXI. századon [People who have left their mark on the 20th century]. Napvilág Kiadó, Budapest.

Keynes, M. J. (1936): The General Theory of Employment, Interest and Money. Macmillan, London.

Lentner, Cs. (2018): Pages in History. Welcome by the Editor in-Chief. Polgári Szemle, Vol. 14, No. 4-6, pp. 11-14, https://doi.org/10.24307/psz.2018.1202.

Matolcsy, Gy. (ed.) (1999): Növekedés és globalizáció. Válogatott tanulmányok [Growth and globalisation. Selected essays]. Kairosz Kiadó and Economic Growth Institute, Budapest.

Samuelson, P. A. (1946): Lord Keynes and the General Theory. Econometrica, Vol. 14, No. 3. 